\title{
Assessment of cow and farm level risk factors associated with Ureaplasma diversum in pasture-based dairy systems - A field study
}

\author{
JOSEFA M. NASCIMENTO-ROCHA ${ }^{1}$, BENEDITO D. DE OLIVEIRA FILHO ${ }^{2}$, EMANNUEL \\ ARNHOLD $^{2}$, REGIANI N.G. PÔRTO ${ }^{2}$, SVETLANA F. LIMA ${ }^{3}$ and MARIA LUCIA GAMBARINI ${ }^{2}$ \\ ${ }^{1}$ Instituto Tocantinense Presidente Antonio Carlos, Rua 02, s/n, Quadra 07, \\ Jardim dos Ypes, 77500-000 Porto Nacional, TO, Brazil \\ ${ }^{2}$ College of Veterinary and Animal Sciences, Federal University of Goias, Campus Samambaia, \\ Av. Esperança, s/n, Campus Universitario, 74690-900 Goiania, GO Brazil \\ ${ }^{3}$ Department of Population Medicine and Diagnostic Sciences, College of Veterinary \\ Medicine, Cornell University, 14853, Ithaca, NY, United States of America
}

Manuscript received on November 21, 2016; accepted for publication on March 20, 2017

\begin{abstract}
Potential risk factors for Ureaplasma diversum in the vaginal mucus of 1,238 dairy cows were included in a multivariate logistic regression model, based on the cow level (i.e., granular vulvovaginitis [+GVV], yearly milk production [4500 kg or more], pregnancy, predominance of Bos taurus [+Bos Taurus], score of corporal condition [at least 2.5], concomitant positivity for Escherichia coli [+E.coli]), and farm level i.e., milking room hygiene (-Milking room), dunghill location, and replacement female). Ureaplasma diversum was present in $41.1 \%$ of the samples. Independent risk factors for $U$. diversum were $+\mathrm{GVV}$ (odds ratio [OR], 1.31); +Mycoplasma spp (OR, 5.67); yearly milk production (4500 kg or more) (OR, 1.99); +Bos taurus (OR, 1.68); +E. coli (OR, 4.96); -milking room (OR, 2.31); and replacement females (OR, 1.89). Ureaplasma diversum vaginal colonization was strongly associated with Mycoplasma spp., E. coli, and number of pregnant cows.
\end{abstract}

Key words: dairy cow, exposure factors, genital ureaplasmosis, mollicutes.

\section{INTRODUCTION}

Ureaplasma diversum is an opportunistic mollicute associated with granular vulvovaginitis (GVV) in cattle (Buzinhani et al. 2007). GVV is also associated with the presence of Mycoplasma bovis and Mycoplasma bovigenitalium (Buzinhani et al. 2007, Lysnyansky et al. 2009). Mollicutes may be found alone or in association with other

Correspondence to: Maria Lucia Gambarini

E-mail: mlgambarini@pq.cnpq.br microorganisms such as Pasteurella multocida and $P$. haemolytica, which have been associated with respiratory diseases in calves (Hirose et al. 2003), and may play a role in the severity of pathological processes and in predisposing an animal to infection of the lower respiratory tract (Virtala et al. 1996). In other species, this synergistic role was studied in the airsacculitis in gnotobiotic chickens (Springer et al. 1974) and in women with spontaneous abortion or preterm delivery (Raddi and Lorencetti 1998). 
In the cow one of the signs of the infection by Mollicutes, the GVV, is an inflammation characterized by hyperaemia and nodules containing lymphocytes and plasmocytes in the lamina propria of the mucosa. Cows may present with GVV three to six days postbreeding (Doig et al. 1979). GVV can be classified into different grades, according to the amount and distribution of nodules in the mucosa and the grade of hyperaemia (Gambarini et al. 2009).

It is considered a commensal organism, although it has been associated with GVV outbreaks (Lysnyansky et al. 2009). Experimental infections and clinical isolates from commercial herds indicate that mollicutes are associated with GVV and significantly affect reproductive efficiency by increasing the number of days of open breeding and the number of repeat breeding cows (Nascimento et al. 2005, Buzinhani et al. 2007, Gambarini et al. 2009). Besides the reproductive tract, $U$. diversum inhabits all mucosal membranes and causes a subclinical respiratory infection and bronchopneumonia in calves (Brown 2010). In Cuba, it was detected in pneumonic lung samples of pigs (Burgher et al. 2014). In Brazil, a previous study adopted a multivariate logistic regression and observed that the presence of vulvar lesions and the use of progesterone devices during reproductive protocols were significantly associated with the presence of $U$. diversum (Gaeti et al.2014). Granular vulvovaginitis in cows has been associated also with bovine herpesvirus type 1 (BHV-1) (Wentink et al. 2000, Van Schaik et al. 2002, Anderson 2007), but microbiological and serological assessments of cows presenting different grades of GVV show that it is not an exclusive reaction to BHV-1 (Blum et al. 2007).

$U$. diversum can be detected inside cells or adhered to their surfaces (Marques et al. 2010) and induced significant TNF-alpha production in the uterus of mice (Silva et al. 2016), indicating that the colonization of the reproductive tract of females may alter the homeostasis of the uterus microenvironment (Marques et al. 2016). Recent studies using the metagenomic to evaluate the progression of the uterine microbiota from calving until establishment of metritis have shown that among 824 bacteria genera found in uterine samples of metritic and non metritic cows, Ureaplasma was present in $5.2 \%$, with a relative increasing in the number of positive samples for this bacterium from 0 to 2 days post partum, and then decreasing from 2 to $6 \pm 2$ days post partum (Jeon et al. 2015).

Cell invasion by the mollicutes has been described in phagocytic and nonphagocytic cells, and the recurrence and/or chronicity of genital mycoplasmosis can be explained by immune escape mechanisms (Rottem 2003). This may enhance the understanding of biological changes in the mollicutes as a mechanism of adaptation to the host and understanding its transmission, which was previously reported in studies investigating the invasion of Trichomonas vaginalis by Mycoplasma hominis (Vancini and Benchimol 2008). The findings that the reference strains and clinical isolates of $U$. diversum are able to invade human epithelial type 2 (HEP-2) cells one minute after infection is the fact that allows identifying the agent as a cellular invader in mammals and explains its impact on bovine mycoplasmosis (Marques et al. 2010).

Little is known about the possible risk factors associated with genital ureaplasmosis in bovines, which may occur by venereal transmission during natural mating or artificial insemination ( $U$. diversum has been detected in bovine semen straws), indicating a large-scale risk of dissemination in herds (Marques et al. 2009). Other potential routes of dissemination are embryo transfer (Britton et al. 1988), contact between confined animals (Sanderson et al. 2000) or contact between animals maintained in groups for reproductive management (Gambarini et al. 2009), and during milking (Maunsell and Donovan 2009). Risk factors can 
be defined as the measurable characterization of diverse conditions that contribute to or increase the probability of a disease and can be related to the individual, the environment, or social media. For lactating cows, high production, parity, and calving season are risk factors for reproductive disorders, increasing the number of days open, services per conception, and the rate of involuntary culling (Gröhn and Rajala-Schultz 2000). Identifying risk factors should take into consideration the differences in the occurrence of the problem, based on comparisons between individuals or groups with different levels of a proposed factor (Sargeant et al. 1998).

Studies involving Bos taurus females in a tropical environment show that breed, parity, and age increase the chances of dairy cattle testing positive for $U$. diversum (Leon et al. 1995). The identification of potential risk factors may assist in the decision-making process to minimize the effect on the animal and to manage its dissemination in the herd (Givens and Marley 2008).

This study was performed to verify the presence of $U$. diversum in the vaginal content of cows with and without the typical lesions of granular vulvovaginitis, and to evaluate its correlation with potential risk factors inherent to the animal and to the production system.

\section{MATERIALS AND METHODS}

This study was conducted according the Brazilian guideline for the care and use of animals in education and scientific research activities (DBCA) and was approved by the Ethics Committee for the use of animals of the Federal University of Goias, Brazil.

\section{STUDY SITE}

Fifteen commercial pasture-based dairy farms (DFs) were visited, and 1,238 cows were sampled. The DFs were located in the middle west region of Brazil, the Cerrado biome, located in two mesoregions (central and south): latitude between $-16^{\circ} 01^{\prime} 13^{\prime \prime}$ and $17^{\circ} 47^{\prime} 53^{\prime \prime}$; longitude between $49^{\circ} 18^{\prime} 40^{\prime \prime}$ and 50 55' 41"; altitude between 716 and 948 meters above sea level; average temperature between $23^{\circ} \mathrm{C}$ and $31^{\circ} \mathrm{C}$; and rainfall between $50-180 \mathrm{~mm}$.

\section{SAMPLING AND ASSESSMENT OF RISK FACTORS}

For this study, the DFs were selected, according to the following criteria: pasture-based system, participation in monitoring programs by a veterinarian, use of artificial insemination, strict observation of the compulsory prophylactic calendar, and at a distance of maximum $200 \mathrm{~km}$ from the University campus. All DFs were engaged in an extension program conducted by the same milk industry. In the DFs, all lactating cows with 90-100 days in milk and parity between 2 and 3 were sampled, except cows with a history of abortion, premature calving, stillborn birth, placenta retention, and/or puerperal metritis in the previous pregnancy.

The DFs were visited by the same team that collected and processed the vaginal mucus. The DFs were evaluated under two aspects, based on potential risk factors as follows:

- Cow level, in relation to the presence of GVV, yearly milk production (at least 4500 $\mathrm{kg})$, pregnancy $(+,-)$, predominance of Bos taurus in crossbreeding ( + Bos taurus), score of corporal condition (SCC) of 2.5 or greater, and positive cultures of the vaginal content for Escherichia coli $(+$ E. coli).

- Farm level, relating to hygiene in the milking room [-Milking room, if one of the four points failed - removal of feces during milking, use of paper towel to clean teats, washing the milking parlor only after all groups of cows were milked, use of detergents to clean the milking room), 
dunghill location $(<50 \mathrm{~m})$, and purchase of replacement females (in the last six months).

After the sample processing, one additional factor was added to the inherent conditions of the cows: concomitant positive isolation of Mycoplasma spp (+Mycoplasma).

In all DFs, the same veterinarian performed sampling during milking. Each cow was evaluated and sampled once. The vulvovaginal mucosa was assessed for the presence of GVV and classified as "absent" or "present", as adapted from Gambarini et al. (2009). The subsequent procedure consisted of dry cleaning the perineal and vulvar regions and collecting vaginal mucus by using two sterile swabs rubbed on the mucosa. The first sample was placed in an $\mathrm{A}_{3 \times \mathrm{B}}$ transport medium (Cunha et al. 1987) and used for the isolation of Mollicutes, and the second sample was placed in thioglycolate medium for the isolation of E. coli. All samples were processed within 24 hours of collection. For the isolation of $U$. diversum and Mycoplasma spp., aliquots were inoculated in $\mathrm{Ub}$ medium, agar $\mathrm{Ub}$, and agar Hayflick, incubated, and evaluated as described by Ruhnke and Rosendal (1994). Briefly, agar plates were incubated for up to 15 days, at $37^{\circ} \mathrm{C}$ in a microaerophilie environment (atmosphere of $85 \% \mathrm{~N}_{2}, 10 \% \mathrm{CO}_{2}$ and $5 \% \mathrm{O}_{2}$. The broths were incubated in aerobic atmosphere during 5 days at $37^{\circ} \mathrm{C}$.

The tubes and plates were examined daily to assess the urease activity and presence of small dark brown-colored granular colonies ( $U$. diversum) and to identify "fried egg" colonies (a characteristic of the mycoplasmas), which were confirmed by Dienes staining. For the isolation of $E$. coli, the samples were processed according to Oliveira (1995).

\section{STATISTICAL ANALYSIS}

The descriptive statistics was generated, and the distribution of the frequency of animals positive or negative for $U$. diversum and potential risk factors were assessed. Possible collinearity between variables was determined by the chi-squared test. Multivariate analysis was performed by using a logistic regression model that included $+\mathrm{GVV}$; SCC of 2.5 or greater; + Mycoplasma spp.; yearly milk production of at least $4500 \mathrm{~kg}$; + pregnancy; +Bos taurus; +E. coli; -Milking room; dunghill location less than $50 \mathrm{~m}$; and the purchase of replacement females. Data analysis was performed by using the software R (R Core Team, 2013) with the glmer function of the lme4 package (Bates et al. 2013).

\section{RESULTS}

Out of the 1,238 vaginal mucus cultures, $41.1 \%$ tested positive for $U$. diversum. The prevalence of $U$. diversum for the DFs ranged between $20 \%$ and $79 \%$. Table I shows the frequency of the distribution of the categorical variables that were assessed as potential risk factors for $U$. diversum positivity. Table II shows the odds ratio (OR) and the $\mathrm{P}$ values resulting from the model of multivariate logistic regression for the 1,238 cows assessed for the presence of $U$. diversum. +Pregnancy and a SCC of 2.5 or greater did not show significant results in the first model $(\mathrm{P}>0.05)$, although the frequency of samples positive for $U$. diversum has been higher than $40 \%$.

Independent risk factors for $U$. diversum associated with the cow level were $+\mathrm{GVV}(\mathrm{OR}$, 1.31, $\mathrm{P}<0.001)$, +Mycoplasma spp (OR, 5.67, $\mathrm{P}$ $<0.0001$ ), yearly milk production of at least 4500 $\mathrm{kg}$ (OR, 1.99, $\mathrm{P}<0.05)$; + Bos taurus (OR, 1.68, $\mathrm{P}<0.001)$, and $+E$. coli in the vaginal mucus (OR, 4.96, $\mathrm{P}<0.001)$. This means that there are significant associations between these variables and positive vaginal samples for $U$. diversum. The most significant results were that the presence of Mycoplasma spp was 5.67-fold higher in females positive for $U$. diversum and 4.96-fold higher in cows with $E$. coli positive vaginal mucus samples. 
TABLE I

Distribution of risk factors related to vaginal positive samples to Ureaplasma diversum on the 1,238 evaluated cows and 15 Dairy Farms Systems.

\begin{tabular}{ccccccc}
\hline & & \multicolumn{3}{c}{ Ureaplasma diversum } \\
\cline { 3 - 6 } & & & \multicolumn{2}{c}{ Positive } & \multicolumn{2}{c}{ Negative } \\
& Level & $\mathbf{N}$ & $\mathbf{n}$ & $\mathbf{( \% )}$ & $\mathbf{n}$ & $\mathbf{( \% )}$ \\
\hline $\begin{array}{c}\text { Number of } \\
\text { sampled cows }\end{array}$ & 1,238 & $509(41.1)$ & $729(58.9)$
\end{tabular}

Cow level

\begin{tabular}{|c|c|c|c|c|}
\hline$+\mathrm{GVV}$ & No & 481 & $200(41.6)$ & $281(58.4)$ \\
\hline \multirow{3}{*}{$\begin{array}{c}\text { + Mycoplasma } \\
\text { spp }\end{array}$} & Yes & 757 & $309(40.8)$ & $448(59.2)$ \\
\hline & No & 925 & $276(29.8)$ & $649(70.2)$ \\
\hline & Yes & 313 & $233(74.4)$ & $80(25.6)$ \\
\hline \multirow{2}{*}{$\begin{array}{c}\text { Milk } \\
\text { production } \\
\geq 4500 \mathrm{Kg} / \mathrm{milk} / \\
\text { year }\end{array}$} & No & 258 & $127(49.2)$ & $131(50.8)$ \\
\hline & Yes & 980 & $382(39.0)$ & $598(61.0)$ \\
\hline \multirow[t]{2}{*}{+ Pregnancy } & No & 823 & $338(41.1)$ & 485 (58.9) \\
\hline & Yes & 415 & $171(41.2)$ & $244(58.8)$ \\
\hline \multirow[t]{2}{*}{+ Bos taurus } & No & 531 & $167(31.5)$ & $364(68.5)$ \\
\hline & Yes & 707 & $342(48.4)$ & $364(51.6)$ \\
\hline \multirow[t]{2}{*}{$\mathrm{SCC}>2.5$} & No & 833 & $333(39.9)$ & $500(60.1)$ \\
\hline & Yes & 405 & $155(38.3)$ & $250(61.7)$ \\
\hline \multirow[t]{2}{*}{+ E. coli } & No & 806 & $255(31.6)$ & $551(68.4)$ \\
\hline & Yes & 432 & $304(70.3)$ & $127(29.4)$ \\
\hline
\end{tabular}

Farm level

$\begin{array}{ccccc}\text {-Milking room } & \text { No } & 842 & 316(37.5) & 526(62.5) \\ & \text { Yes } & 396 & 193(48.7) & 203(51.3) \\ \text { Dunghill }<50 \mathrm{~m} & \text { No } & 840 & 351(41.8) & 489(58.2) \\ & \text { Yes } & 398 & 158(39.7) & 240(60.3) \\ \begin{array}{c}\text { Purchase of } \\ \text { replacement } \\ \text { females }\end{array} & \text { No } & 847 & 350(41.3) & 497(58.7) \\ & \text { Yes } & 391 & 159(40.7) & 232(59.3)\end{array}$

TABLE II

Results of multivariable logistic regression analysis of risk factors between vaginal positive samples to Ureaplasma diversum and independent variables on the 1,238 evaluated cows and 15 Dairy Farms Systems.

\begin{tabular}{cccccc}
\hline Variable & OR & C.I. & P-value \\
\hline Cow level & & & & \\
+ GVV & 1.31 & 1.12 & 1.54 & $<0.001$
\end{tabular}

$\begin{array}{lllll}+ \text { Mycoplasma spp } & 5.67 & 4.16 & 7.72 & <0.0001 \\ & & & & \\ \begin{array}{c}\text { Milk production } \\ \geq 4500 \mathrm{Kg} / \mathrm{milk} / \\ \text { year }\end{array} & 1.99 & 1.09 & 2.08 & <0.05\end{array}$

$\begin{array}{lllll}+ \text { Pregnancy } & 0.95 & 0.72 & 1.24 & \text { NS }\end{array}$

$\begin{array}{lllll}+ \text { Bos Taurus } & 1.68 & 1.23 & 2.05 & <0.001\end{array}$

$\begin{array}{lllll}\mathrm{SCC} \geq 2.5 & 0.89 & 0.69 & 1.15 & \mathrm{NS}\end{array}$

$\begin{array}{lllll}+ \text { E coli } & 4.96 & 3.21 & 7.66 & <0.001\end{array}$

$\begin{array}{lllll}+ \text { E. coli } \text { and } & 5.15 & 3.46 & 7.68 & <0.001\end{array}$

Farm level

$\begin{array}{llll}\text {-Milking room } \quad 2.31 \quad 1.71 & 3.12 \quad<0.001\end{array}$

$\begin{array}{lllll}\text { Dunghill }<50 \mathrm{~m} \quad 1.71 & 0.52 & 1.95 & \text { NS }\end{array}$

Purchase of

$\begin{array}{lllll}\text { replacement } & 1.89 & 1.38 & 2.57 & <0.001\end{array}$ females

\footnotetext{
* Mantel-Haenszel chi-squared test.
} 
In the final multivariate logistic regression model, the probability of samples positive for $U$. diversum was $73.1 \%$ for cows with $+\mathrm{GVV}$, + Mycoplasma spp., pregnancy+, yearly milk production of at least $4500 \mathrm{~kg},+$ Bos Taurus, and $+E$. coli. The results showed a positive association between $U$. diversum and $+E$. coli (OR 4.96, 3.21-7.66, $\mathrm{P}<0.001)$, and between $+E$. coli and +pregnancy (OR 1.78, 95\% CI, 1.32-2.10, P < $0.01)$. Therefore, to address confounding factors, the Mantel-Haenszel chi-squared test was applied to stratify by the variable of + pregnancy with regard to the presence of $U$. diversum and $+E$. coli. The adjusted OR was 5.15 (95\% CI, 3.46-7.68, P $<0.001$ ), which showed a significant association between these three variables, that mean, the probability of $U$. diversum positive vaginal mucus is 5.15-fold higher in pregnant cows presenting also $E$. coli in the vaginal mucus. At the farm level, independent risk factors were the -Milking room (OR 2.31, $\mathrm{P}<0.001)$ and the purchase of replacement females $(1.89, \mathrm{P}<0.001)$. The probability of cows positive for $U$. diversum was $43 \%$ for -Milking room and $41 \%$ in the farms that purchased replacement females. No association was found with a dunghill located less than $50 \mathrm{~m}$.

\section{DISCUSSION}

Data are often contradictory concerning the clinical importance of the involvement of ureaplasmas in reproductive disturbances in humans and animals. The lack of a cell coat, a saprophytic and facultative anaerobic condition, its high affinity for an epithelial surface, and its resistance to temperature changes favor its survival and dissemination. However, in many studies, differences in serotypes and in the pathogenicity of the strains make interpretation difficult. The average percentage (41.1\%) of cows positive for $U$. diversum in the present study is similar to the percentage previously reported in Brazil and in other countries. In cattle, the presence of $U$. diversum has been reported in many countries (Canada, Costa Rica, France, England, United States of America, Brazil), and most recently in Australia, where researchers hypothesize that the lack of association between reproductive diseases and $U$. diversum detection may be caused by missing data or by misdiagnosed problems (Argue et al. 2013). Some research teams have linked the identification of this bacterium with abortion, after performing additional tests in animals that had not been diagnosed through routine procedures (Watson et al. 2012). This confirms data published in Finland (Syrjälä et al. 2007).

In the present study, all DFs had positive cows for $U$. diversum and GVV, and of the 509 samples positive for $U$. diversum, 200 (39.8\%) samples were obtained from cows without GVV; of 729 samples negative for $U$. diversum, 448 (61.6\%) had GVV.

In Canada, the evaluation of dairy cows with and without GVV showed a frequency of $43.3 \%$ for $U$. diversum (Mulira et al. 1992); in France, $40 \%$ of the samples were positive for $U$. diversum, although without a relationship with GVV (Le Grand et al. 1995). In the tropical climate conditions of Brazil, positive isolation of $U$. diversum was reported for the first time in 2000 (Cardoso et al. 2000) in mucus from cows with reproductive disorders and GVV with a frequency of $52.6 \%$ in Holstein cows and $23.7 \%$ in Jersey cows. In Austria, U. diversum was present in all studied farms with $35.5 \%$ of the animals testing positive for the organism, which was associated with vaginitis (Petit et al. 2008). Previous studies reported a predominance of mild GVV in more than $50 \%$ of repeat breeding dairy cows with samples positive for $U$. diversum associated with this lesion grade (Oliveira Filho et al. 2005). In beef heifers, there was a predominance of mild to severe GVV that was also associated with $U$. diversum (Gambarini et al. 2009). There was an association between mild GVV and $U$. diversumpositive samples in replacement beef heifers, but a tendency was verified for higher calving rates in 
heifers negative for $U$. diversum (Sanderson et al. 2000).

The local reaction of the macroscopic aspect of the GVV may be related to the virulence of the strain. The immunological response depends on the virulence of the strain and the local mechanisms of cell response. These results in individual variations related to breed, productivity, and other concomitant infections. The preferred attachment site of $U$. diversum is epithelial tissue, particularly respiratory and genital epithelial cells. $U$. diversum can therefore be considered a surface parasite (Rottem 2003). In the present study, the presence of mollicutes in vaginal mucus was assessed by cultured samples. However, using polymerase chain reaction (PCR) increased the detection of $U$. diversum from $25 \%$ to $37.5 \%$, which is the percentage of positive samples from cows with reproductive disorders (Buzinhani et al. 2007). This indicates that these bacteria may be present in a larger number of cows in the studied DFs. An ascending infection can be one mechanism of choice for uterine and fetal contamination; this combination would be harmful for reproductive health and must be evaluated in reproductive failures, abortion, stillborn, weak newborn calves, and bronchopneumonia in young calves (Brown 2010). Mild GVV and the presence of $U$. diversum indicates the acute phase of vulvovaginitis, as previously reported in experimental infections by uterine and cervical inoculation in heifers (Doig et al. 1980). A $+\mathrm{GVV}$ was most frequent in pregnant and + Mycoplasma spp cows.

The present data were obtained from dairy cows during a very particular phase of their reproductive cycle because all were 90-100 days in milk, had regular estrus cycle intervals after calving, and were under a regular program of artificial insemination. The inclusion of the variable $E$. coli in the analysis also increased the odds of positivity to $U$. diversum in cows with + Mycoplasma spp., showing that the colonization of the vaginal mucosa with $E$. coli may favor the proliferation of $U$. diversum and mycoplasmas. When identifying $E$. coli in vaginal samples positive for $U$. diversum, a significant $\mathrm{OR}$ indicates an interaction between E.coli and the mollicutes, which has been previously reported for mollicutes and streptococci isolated from ulcerative lesions of the genital tract of equines (Spergser et al. 2002) and Pasteurella multocida in lesions of respiratory disorders caused by mycoplasmas in cows (Maunsell and Donovan 2009). The synergism between Gram negative bacteria and the ureaplasmas may exist because of the protein similarity of their membranes (Brenner et al. 1997). Cows with metritis showed a predominance of $E$. coli strains in the vaginal bacterial microbiota with a marked increase of $E$. coli in vaginal samples from infected postpartum cows (Wang et al. 2013). Under natural conditions the vaginal microbiota of cows is stable and may protect the animal from potential pathogenic saprophytic microorganisms. A very low level of Enterobacteriaceae was detected in the heifers and increased during the growth of the animal, which would be associated with the establishment of hormonal cycles resulting from puberty (Otero et al. 2000).

The inclusion of the variable +Pregnancy in the stratified analysis increased the OR (5.15), suggesting that the variable combination of + pregnancy and E. coli play an important role on the probability to obtain $U$. diversumpositive samples in the studied cows population. Immunological suppression to minimize rejection of paternal antigens and escape mechanisms against phagocytosis present in mollicutes may explain this finding (Kwiecien and Little 1991). Pregnant females are immunologically suppressed with reduced circulation of $\mathrm{T}$ cells and $\mathrm{B}$ cells in the reproductive system to reduce the risk of rejection to paternal antigens acquired during conception. The mollicutes have escape mechanisms against phagocytosis while they are in an extracellular medium (e.g., in the mucosa of 
the reproductive tract), reducing the possibility of bacterial recognition when they later invade the cells (Kwiecien and Little 1991).

Bos taurus cows, especially the Jersey breed, have a greater probability of being positive for mollicutes. All farms visited in the present study were pasture-based systems in which Bos taurus $\times$ Bos indicus crossbreeds predominate. Thus, racial characteristic was classified with regard to the predominant breed (i.e., taurine or zebuine). The results demonstrate that the cows that are predominantly Bos taurus are 1.68 times more likely to be positive for $U$.diversum $(\mathrm{P}<0.001)$ than those predominately Bos indicus. This risk factor was identified in $U$. diversum infections (León et al. 1995, Cardoso et al. 2000, Bey 2006). When the results of $U$. diversum are compared among Bos taurus and Bos indicus, the frequency was higher between Nellore females, followed by Jersey cows and Holstein cows (Cardoso et al. 2000). The milk production was not high in any of the visited farms, although cows of predominant Bos taurus breed tend to produce more milk and are more likely to demonstrate stressed behavior (Gröhn and RajalaSchultz 2000, Gábor et al. 2008), which contributes to the manifestation of diseases or functional alterations.

In this study, three factors on the farm level were assessed as probable variables related to the higher frequency of samples positive for $U$. diversum. These factors were selected because of the possibility of using the same evaluation profile for all farms, unlike other factors that are related to sanitary conditions (e.g., application of pre- and post-dipping or protocols of treatment), which differ according to the procedures adopted and the products used. Two variables were confirmed as risk factors inherent to the system. Poor hygiene in the milking room showed the highest odds with a 2.31 times increased risk of the cows being positive. Mollicutes are very susceptible to adverse environmental conditions and respond by cell lysis to osmotic shock caused by detergents (Chambaud et al. 1999). However, cleaning the milking room with only water or with an inadequate amount of detergent is insufficient to eliminate the agent and is a risk factor in the maintenance of microorganisms in the ambient environment (Vairamuthu et al. 2010). It also increases the risk of their dissemination by the hands of the milker (Al-Momani et al. 2008). The mollicutes can adapt themselves to different hosts, and mutations have been reported as a survival mechanism (Yogev et al. 2002).

M. bovis has been isolated from bovine feces up to 37 days after contamination (Caswell and Archambault 2007). The transmission to other hosts from contaminated dung has been suggested (Madoff et al. 1979, Pitcher and Nicholas 2005). The urea present in the urine incorporated in the material sent to the dunghills may contribute to the survival of $U$. diversum, which uses it as a nutritional source. Ureaplasmas are microaerophilic, and although the optimum temperature for their growth is $37^{\circ} \mathrm{C}$, they can grow in a temperature range of 22 $42^{\circ} \mathrm{C}$ (Brown 2010). In regard to the environmental temperature for most of the year in tropical regions, the adaptation of this microorganism may favor its survival in the environment of the milking room and in the dunghill.

The odds ratio for cows being positive to $U$. diversum was 1.89 times higher in DFs that purchase replacement cows $(\mathrm{P}<0.001)$. The purchase of an animal increases the risk of spreading diseases because new animals may already be contaminated, because of the stress caused by transportation and because adaptation temporally inhibits the immune system (Van Schaik et al. 2002). Clinical signs of genital infection by mollicutes are usually reported when the female is been evaluated to be introduced or to return to the reproductive management, that is, when she is considered apt to reproduction. The infected cow is included in the routine reproductive management and repeatedly returns in estrus, after 
artificial insemination or natural mating. Even GVV (which researchers indicate as a signal of genital infection by mollicutes), if not severe enough to cause discomfort to the animal, would not be considered a primary cause of a return to estrus. Thus, the replacement female may act as a source of dissemination.

In conclusion, the colonization of the vaginal mucosa with $U$. diversum was strongly associated with the presence of Mycoplasma spp. and E. coli, and with positive pregnancy in the studied population. The results showed that screening for risk factors at the cow and farm level should allow better assessment of the risk of obtaining cultures positive for $U$. diversum in dairy cows. Cows presenting GVV probably are infected with Mollicutes, the predominance of Bos taurus in the crossbreed favors the vaginal colonization by these bacteria and, a new finding, that there is a bacterial synergism action between Mollicutes and E. coli would allow future studies to establish prophylactic and control measures, and a better understanding of asymptomatic reproductive infections in dairy cows and their newborn calves. On the farm level, the association of $U$. diversum with two hygienerelated variables highlights the importance of the periodical screening of the dairy system.

\section{ACKNOWLEDGMENTS}

This project was supported by the Conselho Nacional de Desenvolvimento Científico e Tecnológico (CNPq), Brazil, (Process \#478716/2006-0), a research grant to M L Gambarini and an undergraduate scholarship to S F Lima.

\section{REFERENCES}

AL-MOMANI W, NICHOLAS RA AND ABO-SHEHADA MN. 2008. Risk factors associated with Mycoplasma agalactiae infection of small ruminants in northern Jordan. Prev Vet Med 83: 1-10.

ANDERSON ML. 2007. Infectious causes of bovine abortion during mid- to late-gestation. Theriogenology 68: 474-486.
ARGUE B, CHOUSALKAR KK AND CHENOWETH PJ. 2013. Presence of Ureaplasma diversum in the Australian cattle population. Aust Vet J 91: 99-101.

BATES D, MAECHLER M AND BOLKER B. 2013. lme4: Linear mixed-effects models using S4 classes. R package version 0.999999-2. http://CRAN.R-project.org/ package $=1 \mathrm{me} 4$.

BEY I. 2006. Les ureaplasmes en pathologie bovine: Epidemiologie, diagnostic et mesures de controle. Universite Claude-Bernard, Lyon. França. Tese de doutorado, I, 19, $90 \mathrm{p}$.

BLUM SA, MAZUZ MB, BRENNER JC, FRIEDGUT OC, STRAM YC, KOREN OD, GOSHEN TD AND ELAD D. 2007. Sample-based assessment of the microbial etiology of bovine necrotic vulvovaginitis. Theriogenology 68: 290-293.

BRENNER C, WROBLEWSKI H, HENAFF ML, MONTAGNIER L AND BLANCHARD A. 1997. Spiralin, a mycoplasmal membrane lipoprotein, induces T-cell-independent B-cell blastogenesis and secretion of proinflammatory cytokines. Inf Imm 65(10): 4322-4329.

BRITTON AP, MILLER RB, RUHNKE HL AND JOHNSON WH. 1988. The recovery of Ureaplasmas from bovine embryos following in vitro exposure and ten washes. Theriogenology 30: 997-1003.

BROWN DR. 2010. Phylum XVI. Tenericutes. In: De Vos P et al. (Eds), Bergey's Manual of Systematic Bacteriology, $2^{\text {nd }}$ ed., vol. 3, Springer, New York, NY, p. 253-408.

BURGHER Y, MIRANDA L, RODRIGUEZ-ROCHE R, ALMEIDA AC, LOBO E, NEVES T, MARTÍNEZ O and TIMENETSKY J. 2014, Ureaplasma diversum in pneumonic lungs of swine. Infect Genet Evol 21: 486-488.

BUZINHANI M, METIFFOGO E AND TIMENETSKY J. 2007. Detecção de Mycoplasma spp. e Ureaplasma diversum em vacas com distúrbios reprodutivos. Braz $\mathrm{J}$ Vet Anim Sci 59(6): 1368-1375.

CARDOSO MV, SCARCELLI E, GRASSO LM, TEIXEIRA SR AND GENOVEZ ME. 2000. Ureaplasma diversum and reproductive disorder in Brazilian cows and heifers; first report. Anim Reprod Sci 3-4(1): 137-143.

CASWELL JLAND ARCHAMBAULT M. 2007. Mycoplasma bovis pneumonia in cattle. Anim Health Res Rev 8(2): 161-186.

CHAMBAUD I, WRÓBLEWSKI H AND BLANCHARD A. 1999. Interactions between Mycoplasma lipoproteins and the host immune system. Trends Microbiol 7(12): 493499.

CUNHA RAF, TAKIMOTO S AND TAKEI K. 1987. Modificação e padronização de meios de transporte e cultivo de Mycoplasmas genitais: Mycoplasma hominis e Ureaplasma urealyticum. Rev Farm Bioquím Univ São Paulo 23: 170-177. 
DOIG PA, RUHNKE HL AND PALMER NC. 1979. Bovine granular vulvitis associated with Ureaplasma infection. Cann Vet J 20: 89-94.

DOIG PA, RUHNKE HL AND PALMER NC. 1980. Experimental bovine genital ureaplasmosis. I. Granular vulvitis following vulvar inoculation. Can J Comp Med 44: 252-258.

GÁBOR G, TÓTH F, ÓSVARI L, ABONYI-TÓTH Z AND SASSER RG. 2008. Factors influencing pregnancy rate and late embryonic loss in dairy cattle. Reprod Domest Anim 43: 53-58.

GAETI JGLN ET AL. 2014. Ureaplasma diversum as a cause of pustular vulvovaginitis in bovine females in Vale Guapore, Mato Grosso State, Brazil.Trop Anim Health Pro 46: 1059-1063.

GAMBARINI ML, KUNZ TL, OLIVEIRA FILHO BD, PORTO RNG, OLIVEIRA CM, BRITO WM AND VIU MA. 2009. Granular vulvovaginitis syndrome in Nelore pubertal and post pubertal replacement heifers under tropical conditions: role of Mycoplasma spp., Ureaplasma diversum and BHV-1. Trop Anim Health Pro 41: 14211426.

GIVENS MD AND MARLEY MS. 2008. Infectious causes of embryonic and fetal mortality. Theriogenology 70: 270285.

GRÖHN YT AND RAJALA-SCHULTZ PJ. 2000. Epidemiology of reproductive performance in dairy cows. Anim Reprod Sci 60(61): 605-614.

HIROSE K, KOBAYASHI H, ITO N, KAWASAKI Y, ZAKO M, KOTANI K, OGAWA H AND SATO H. 2003. Isolation of Mycoplasmas from nasal swabs of calves affected with respiratory diseases and antimicrobial susceptibility of their isolates. J Vet Med Series B 50: 347-351.

JEON SJ ET AL. 2015. Uterine Microbiota and Immune Parameters Associated with Fever in Dairy Cows with Metritis. Appl Environ Microbiol 81(18): 6324-6332.

KWIECIEN JM AND LITTLE PB. 1991. Haemophilus somnus and reproductive disease in the cow: a review. Can Vet J 32: 595-601.

LE GRAND D, POUMARAT F AND MARTEL JL. 1995. Infectious genital disease by Ureaplasma diversum, investigations on bovine in France. Vet Res 26: 11-20.

LEÓN BA, CAMPOS E, BOLAÑOS H AND CABALLERO M. 1995. Risk factors for Ureaplasma diversum infection in cattle in a tropical environment. Rev Biol Trop 43(1-3): 21-25.

LYSNYANSKY I, BRENNER J, ALPERT N, BENJAMIN A, BERNSTEIN M, ELAD D, BLUM S, FRIEDGUT O AND ROTENBERG D. 2009. Identification of Mycoplasma bovigenitalium and Mycoplasma canadense from outbreaks of granulopapular vulvovaginitis in dairy cattle in Israel. Vet Rec 165: 319-322.
MADOFF S, PIXLEY BQ, DELGUIDICE RA AND MOELLERING RC. 1979. Isolation of Mycoplasma bovis from a patient with systemic illness. J Clin Microbiol 9: 709-711.

MARQUES LM, BUZINHANI, M, NETO RL, OLIVEIRA RC, YAMAGUTI MY, GUIMARÃES AM AND TIMENETZKY J. 2009. Detection of Ureaplasma diversum in bovine semen straws for artificial insemination. Vet Rec 165: 572-573.

MARQUES LM ET AL. 2010. Invasion of Ureaplasma diversum in Hep-2 cells. BMC Microbiology 10: 83.

MARQUES LM ET AL. 2016. Ureaplasma diversum Genome Provides New Insights about the Interaction of the Surface Molecules of This Bacterium with the Host. PLoS One 11: e0161926.

MAUNSELL FP AND DONOVAN, GA. 2009. Mycoplasma bovis infections in young calves. Clin North Am-Food Anim Prac 25: 139-177.

MULIRA GL, SAUNDERS JR AND BARTH AD. 1992. Isolation of Ureaplasma diversum and Mycoplasmas from genital tracts of beef and dairy cattle in Saskatchewan. Can Vet J 33: 46-49.

NASCIMENTO MGF, D'ANGELIS FHF, NASCIMENTO ER AND RESENDE AO. 2005. Envolvimento de micoplasmas em vacas com distúrbios reprodutivos. Acta Sci Vet 33: 195-199.

OLIVEIRA FILHO BD, PORTO RNG, GAMBARINI ML, KUNZ TL, FERRAZ HT, VIU MAO, LOPES DT AND SOUSA APF. 2005. Isolamento do Ureaplasma diversum em muco vulvovaginal de vacas leiteiras repetidoras de estro no Estado de Alagoas. Braz Arch Vet Sci 10: 151156.

OLIVEIRA SJ. 1995. Guia Bacteriológico Prático. Microbiologia Veterinária. $2^{\mathrm{a}}$ ed., Ed. Ulbra. Canoas, p. 57-60.

OTERO C, SAAVEDRA L, SILVA DE RUIZ C, WILDE O, HOLGADO AR AND NADER-MACÍAS ME. 2000. Vaginal bacterial microflora modifications during the growth of healthy cows. Lett Appl Microbiol 31: 251-254.

PETIT T, SPERGSER J, AURICH J and ROSENGARTEN R. 2008. Prevalence of Chlamydiaceae and Mollicutes on the genital mucosa and serological findings in dairy cattle. Vet Microbiol 127: 325-333.

PITCHER DG AND NICHOLAS RAJ. 2005. Mycoplasma host specificity: fact or fiction? Vet J 170: 300-306.

RADDI MSG AND LORENCETTI NC. 1998. Cervicovaginal aerobic microflora of women with spontaneous abortion or preterm delivery in Araraquara-Brazil. Rev Microbiol 29: 311-313.

R CORE TEAM. 2013. R: A language and environment for statistical computing. R Foundation for Statistical Computing, Vienna, Austria. ISBN 3-900051-07-0, URL http://www.R-project.org/. 
ROTTEM S. 2003. Interaction of Mycoplasmas with host cells. Physiol Rev 83: 417-432.

RUHNKE HL AND ROSENDAL S. 1994. Useful protocols for diagnosis of animal mycoplasmas. In: Whitford HW et al. (Eds), Mycoplasmosis in Animals: Laboratory Diagnosis. Iowa State University Press, Ames, Iowa, p. 141-144.

SANDERSON MW, CHENOWETH APJ, YEARY T AND NIETFELD JC. 2000. Prevalence and reproductive effects of Ureaplasma diversum in beef replacement heifers and the relationship to blood urea nitrogen level. Theriogenology 54: 401-408.

SARGEANT JM, SHOUKRI MM, MARTIN SW, LESLIE KE AND LISSEMORE KD. 1998. Investigating potential risk factors for seasonal variation: an example using graphical and spectral analysis methods based on the production of milk components in dairy cattle. Prev Vet Med 36: 167-178.

SILVA JR, FERREIRA LF, OLIVEIRA PV, NUNES IV, PEREIRA IS, TIMENETSKY J, MARQUES LM, FIGUEIREDO TB AND SILVA RAA. 2016. Intra-uterine experimental infection by Ureaplasma diversum induces TNF-alpha mediated womb inflammation in mice. An Acad Bras Cienc 88: 643-652.

SPERGSER J, AURICH C, AURICH JE AND ROSENGARTEN R. 2002. High prevalence of Mycoplasmas in the genital tract of asymptomatic stallions in Austria. Vet Microbiol 87: 119-129.

SPRINGER WT, LUSKUS C AND POURCIAU SS. 1974. Infectious bronchitis and mixed infections of Mycoplasma synoviae and Escherichia coli in gnotobiotic chickens synergistic role in the air sacculitis syndrome. Infect Immun 10: 578-589.

SYRJÄLÄ P, ANTITLA M, DILLARD K, FOSSI M, COLLIN K, NYLUND M AND AUTIO T. 2007. Causes of bovine abortion, stillbirth and neonatal death in Finland 19992006. Acta Vet Scand 49(suppl. 1): S3.
VAIRAMUTHU S, SINNIAH J AND NAGALINGAM K. 2010. Factors influencing production of hygienic raw milk by small scale dairy producers in selected areas of the Jaffna district, Sri Lanka. Tropl Anim Health Prod 42: 357-362.

VANCINI RG AND BENCHIMOL M. 2008. Entry and intracellular location of Mycoplasma hominis in Trichomonas vaginalis. Arch Microbiol 189: 7-18.

VAN SCHAIK G, SCHUKKEN YH, NIELEN M, DIJKHUIZEN AA, BARKEMAHW AND BENEDICTUS G. 2002. Probability of and risk factors for introduction of infectious diseases into Dutch SPF dairy farms: a cohort study. Prev Vet Med 54: 279-289.

VIRTALA AM, MECHOR GD, GRÖHN YT, ERB HN AND DUBOVI EJ. 1996. Epidemiologic and pathologic characteristics of respiratory tract disease in dairy heifers during the first three months of life. J Am Vet Med Ass 208: 2035-2042.

WANG Y, AMETAJ BN, AMBROSE DJ AND GÄNZLE MG. 2013. Characterization of the bacterial microbiota of the vagina of dairy cows and isolation of pediocin-producing Pediococcus acidilactici. BMC Microbiology 13: 19.

WATSON P, MASON C, STEVENSON H, SCHOLES S, SCHOCK A, MEARS R, YALING R and NICHOLAS R. 2012. Laboratory diagnosis of Mycoplasma/Ureaplasma abortion in cattle. Vet Rec 21: 82-84.

WENTINK GH, FRANKENA K, BOSCH JC, VANDEHOEK JED AND VAN DEN BERG TH. 2000. Prevention of disease transmission by semen in cattle. Livest Prod Sci 62: 207-220.

YOGEV D, BROWING GF AND WISE KS. 2002. Genetic mechanisms of surface variation. In: Razin $\mathrm{S}$ and Herrmann R (Eds), Molecular Biology and Pathogenicity of Mycoplasmas. Kluwer Academic, Dordrecht, the Netherlands, p. 417-444. 